\title{
EVALUASI INPUT KEBIJAKAN PENGEMBANGAN PARIWISATA BERBASIS KEARIFAN LOKAL DI KABUPATEN SIAK
}

\author{
Wazni $^{1)}$, Zulfa Harirah $\mathbf{M S}^{2}$, dan Ramlan Darmansyah ${ }^{3)}$ \\ 1,2,3 Jurusan Ilmu Pemerintahan, Fakultas Ilmu Sosial dan Ilmu Politik,Universitas Riau \\ 1,2,3 Jl. HR. Soebrantas km 12.5 Panam, Pekanbaru

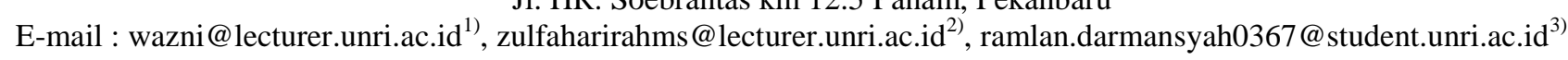

\begin{abstract}
ABSTRAK
Penelitian ini dimaksudkan untuk mengevaluasi input kebijakan pariwisata di Kabupaten Siak yang mengusung pengembangan pariwisata berbasis kearifan lokal. Ide dasar dari tulisan ini berangkat dari kegelisahan dalam mengamati fenomena pengembangan pariwisata berbasis kearifan lokal yang dianggap kuno, tidak menarik dan tertinggal. Terlebih dalam era globalisasi, kekhawatiran akan pudarnya kearifan lokal yang dikelilingi oleh budaya barat dan budaya lainnya menjadi tantangan tersendiri bagi eksistensi kearifan lokal. Namun berbeda yang terjadi di Kabupaten Siak, kearifan lokal justru menjadi daya tawar dalam kebijakan pariwisata. Sehingga menjadi penting untuk melacak penguatan kearifan lokal dalam kebijakan pariwisata Kabupaten Siak dari sisi input kebijakan. Penelitian ini merupakan penelitian kualitatif melalui pendekatan studi kasus. Melalui teori evaluasi kebijakan Stufflebeam, penelitian ini fokus untuk menganalisis input evaluation mengingat aspek input menjadi kunci kesuksesan sebuah kebijakan. Hasil penelitian menunjukkan bahwa kebijakan pengembangan pariwisata tidak dapat dilepaskan dari dukungan input kebijakan berupa sumber daya manusia, sarana dan prasarana, rencana strategis pengembangan pariwisata serta dukungan anggaran. Di Kabupaten Siak, sumber daya manusia yang bekerja pada Dinas pariwisata masih terbatas secara kualitas dan kuantitas. Pengembangan pariwisata di Kabupaten Siak juga dihadapkan pada situasi belum optimalnya pemanfaatan kemajuan teknologi komunikasi dan informasi sebagai salah satu sarana pemasaran dan promosi pariwisata. Dilihat dari regulasi, Kabupaten Siak memiliki keunggulan regulasi melalui visi daerah yang berorientasi pada kebudayaan dan pariwisata, tersedianya roadmap kebudayaan melayu dan PERDA yang mengatur tentang bahasa dan pakaian melayu. Sedangkan dari aspek pendanaan, penyerapan anggaran pada Dinas Pariwisata masih belum maksimal disebabkan oleh keterbatasan sumber daya aparatur yang terlibat dalam pengelolaan kegiatan.
\end{abstract}

Kata Kunci: Evaluasi Kebijakan, Kebijakan Pariwisata, Kearifan Lokal, Budaya Melayu,

\section{PENDAHULUAN}

Kekayaan kultural Kabupaten Siak menjadi daya tarik tersendiri bagi para wisatawan. Hal itu terlihat dari jumlah wisatawan yang datang di Kabupaten Siak selalu bertambah. Interaksi antar pelaku pariwisata merupakan modal utama dalam pengembangan pariwisata berbasis budaya melayu. Pada dasarnya konsep wisata berbudaya melayu merupakan mengintegrasikan nilai keislaman kedalam seluruh aspek kegiatan wisata. Tidak dapat dipungkiri bahwa budaya melayu menjadi budaya yang begitu erat disandangkan dengan agama Islam. Pariwisata berbudaya melayu diwujudkan dalam berbagai sektor, seperti busana melayu, permainan rakyat, rumah makan, transportasi, dll. Nilai halal dan haram menjadi tolak ukur utama bagi setiap pelaku pariwisata.

Kajian mengenai kearifan lokal dan pariwisata bukanlah hal baru yang belum pernah diteliti sebelumnya. Kearifan lokal merupakan warisan budaya secara turun temurun, namun saat ini mulai pudar akibat tergerus arus budaya globalisasi (Hariyanto, 2015). Beberapa penelitian lain telah berupaya memetakan keterkaitan antara kearifan lokal dan pengembangan pariwisata. Harus diakui bahwa budaya dan kearifan lokal yang dimiliki oleh suatu daerah dapat menjadi potensi unggulan pariwisata (Rahmi, 2016). Setiap daerah tentu saja berkepentingan dalam memajukan daya tarik wisata karena mampu menggerakkan ekonomi lokal yang bersifat kerakyatan (George, 2010). Pada saat yang sama, merawat kearifan lokal juga menjadi upaya untuk menjaga aset-aset wisata (Bullen \& Love, 2011).

Pariwisata berbasis budaya cenderung menjual karakteristik khas dari bentuk dan fungsi bangunan bersejarah. Namun persoalan di beberapa kawasan wisata berbasis cagar budaya adalah masalah kerusakan fisik (Sahubawa, Antariksa, \& F.Usman, 2010). Selain faktor kondisi fisik, kondisi lingkungan di sekitar tempat wisata juga berpengaruh dalam mendukung daya tarik wisata (Shankar, 2015). Sehingga keterlibatan semua stakeholders baik Pemerintah, Swasta dan masyarakat mutlak dibutuhkan dalam pengembangan wisata (Caraba, 2011). Termasuk kaitan antara kearifan lokal dan kebijakan publik. Pentingnya kebijakan publik yang melindungi "kekhasan kearifan lokal" perlu dilakukan agar tidak berbenturan dengan local wisdom (Sumada, 2017).

Persaingan di era global yang semakin ketat menjadikan identifikasi terhadap semua faktor daya tarik 
wisata penting untuk dilakukan (Adi \& Saputro, 2017). Pada tataran praktik banyak ditemui realita bahwa pariwisata berbasis kearifan lokal masih sangat terbatas untuk dipromosikan. Penyebabnya beragam, mulai dari kinerja implementator belum maksimal, pendekatan topdown yang menyebabkan rendahnya partisipasi masyarakat, hingga lingkungan sosial, ekonomi dan politik yang justru menghalangi pengembangan pariwisata berbasis kearifan lokal (Jupir, 2013).

Kultur masyarakat memiliki pengaruh terhadap perkembangan wisata di daerahnya. Pengembangan pariwisata yang baik tidak hanya berorientasi pada keuntungan semata, melainkan perlu menaruh perhatian besar pada budaya setempat (Karim, 2010). Dalam era globalisasi, subjek kearifan lokal perlu dilindungi namun tetap mampu mengakomodasi tuntutan globalisasi ekonomi (Irianto, 2016). Kekhawatiran terhadap subjek kearifan lokal dapat mengalami modifikasi budaya, dimana barang-barang budaya menjadi komoditas yang diperjual belikan melalui industri budaya sehingga dikemas berbeda dari nilai-nilai kearifan lokal aslinya (Suneki, 2012).

Di era modernisasi saat ini, keberagaman daya tarik wisata dapat disesuaikan dengan perkembangan zaman, salah satunya adalah dengan menyajikan beragam atraksi wisata yang mendukung eksistensi dan keunikan dari sebuah tempat wisata (Rogerson \& Merwe, 2016). Atraksi wisata yang ditampilkan dapat dipadukan dengan kearifan lokal sehingga memberikan dampak positif bagi masyarakat sekitar. Sehingga diperlukan inovasi dan kreativitas yang menunjukkan kekhasan yang dapat membedakan dengan tujuan wisata daerah lainnya (Bialostocka, 2014).

Selain penelitian diatas, penelitian lain yang mencoba menyoroti pariwisata di Kabupaten Siak juga telah banyak dilakukan. Penelitian sebelumnya tentang pariwisata di Kabupaten siak lebih diarahkan pada branding "Siak the Truly Malay". Salah satunya adalah penelitian yang membuktikan bahwa kegiatan branding ditujukan untuk memperkenalkan Local Branding "Siak the Truly Malay" (Artis, 2016). Strategi dalam mempromosikan city branding tersebut tertuang dalam event-event pariwisata berbudaya melayu (Rosadi \& Medayanti, 2019), memasarkan objek dan produk budaya melayu melalui berbagai saluran komunikasi baik situs online, media elektronik, koran lokal dan publikasi lainnya (Salam \& Nurjanah, 2019).

Kekayaan kultural yang dimiliki masyarakat Riau menjadi daya tarik sendiri bagi para wisatawan. Melalui budaya melayu yang sarat dengan nilai lokal dan keislaman, pariwisata di Riau memiliki kekhasan dan keunikan di bandingkan daerah lain. Di sisi lain, derasnya arus globalisasi justru tetap menjadikan Kabupaten Siak bertahan dengan kearifan lokalnya. Di titik inilah urgensi penelitian ini dilakukan.

Tidak mudah menghadirkan sebuah kebijakan yang bisa diharapkan membawa dampak yang diinginkan di masyarakat, mengingat bervariasinya tuntutan yang harus diakomodir dalam sebuah kebijakan. Kebijakan publik dituntut untuk menyatu dengan kearifan lokal yang ada di masyarakat. Kearifan lokal merupakan nilai yang diaktualisasikan dalam kehidupan sehari-hari dan mencerminkan jati diri masyarakat. Harus diakui bahwa kearifan lokal menjadi "local genius" yang menjadi kekayaan luar biasa suatu bangsa. Sehingga tak heran jika kearifan lokal tidak semata-mata dijunjung sebagai upaya menjaga keharmonisan hubungan manusia tetapi juga sebagai sebuah simbol pengabdian kepada sang pencipta.

Dalam era demokratisasi, pro dan kontra atas sebuah kebijakan adalah lumrah adanya. Sebab, demokrasi menyediakan ruang bagi siapa saja untuk melakukan kontrol atas berjalannya kekuasaan. Dalam banyak hal sistem demokratis memang tumbuh dengan implementasi good governance. Dalam hal ini, kesejajaran ide keduanya dapat dilihat dari perlunya menghadirkan aspek partisipasi, transparansi dan akuntabilitas dalam relasi antara rakyat dalam pelaksanaan good governance (Santoso, 2010). Sehingga tata kelola kebijakan dapat di jabarkan sebagai kebijakan yang lahir dibuat pemerintah adalah dari rakyat dan untuk rakyat.

Kebijakan publik niscaya membentuk lingkungannya sebagai sebuah sistem, baik sosial, ekonomi politik dan budaya. Hubungan timbal balik antara kebijakan dan lingkungan terjadi ketika kebijakan menyalurkan masukannya pada lingkungan sekitar dan pada saat yang sama atau saat yang lain lingkungan juga membatasi perilaku pembuat kebijakan. Ini menunjukkan simbiosis mutualisme antara kebijakan dan lingkungan sekitar. Menurut Robert Eyestone, kebijakan publik merupakan hubungan suatu unit pemerintahan dengan lingkungannya (Alam, 2012). Lingkungan kebijakan terdiri dari dua variabel yaitu variabel kebudayaan politik dan variabel sosial ekonomi.

Pada dasarnya pengembangan pariwisata saat ini telah mengalami pergeseran ke arah pariwisata yang berbasis komunitas dan bersandar pada nilai kearifan lokal. Namun di sisi lain, pembangunan pariwisata tidak akan pernah terlepas dari tuntutan dan mobilitas regional, nasional hingga global. Dalam era globalisasi saat ini, semboyan "think globally act locally" dapat menjadi jurus ampuh menghadapi tantangan. Dimana berfikir secara global namun bertindak secara lokal akan menjadi benteng diri agar tidak terbawa arus kemajuan yang bisa saja menyesatkan.

Kenyataan dalam melakukan upaya pelestarian budaya di era globalisasi masih menyisakan banyak kendala. Secara kasat mata barangkali pariwisata meningkatkan jumlah wisatawan asing namun di sisi lain ada kearifan lokal yang mulai tergerus. Salah satu contoh terjadi di Bali, dimana sektor pariwisata sudah terbukti mampu mendongkrak dan menjadi penggerak roda perekonomian masyarakat Bali. Namun di sisi yang lain, dampak dari pengembangan pariwisata tersebut menyebabkan Bali menjadi bebas (Balquini, 2010). Dilihat dari sisi internal, rasa cinta dan bangga terhadap 
budaya asli masih rendah. Hal ini menjadi salah satu penyebab kearifan lokal tidak dapat bersaing dengan budaya lain. Sedangkan sisi eksternal banyak dipengaruhi oleh media dan semakin mewabahnya budaya modern dari luar yang merasuk ke sendi-sendi masyarakat.

Pariwisata berbasis sejarah dan budaya berbeda dengan wisata yang menyuguhkan panorama perairan laut kepulauan bak sepenggal surga dunia. Destinasi wisata dengan sejuta keindahan alam baik dataran maupun lautan selalu menjadi primadona. Hal ini tentu saja menyisakan pekerjaan rumah bagi wisata berbasis sejarah dan budaya lokal untuk segera berbenah. Ditengah pusaran arus globalisasi yang menuntut serba canggih dan menarik, maka wisata sejarah dan budaya bisa jadi tidak menarik jika tidak dikelola dengan bijak. Oleh sebab itu, penelitian ini berhasrat untuk melacak eksistensi kearifan lokal pada kebijakan pariwisata di Kabupaten Siak di tengah arus globalisasi. Perlu ditelisik lebih dalam bagaimana dukungan input mempengaruhi eksistensi dari budaya melayu itu sendiri bertahan dan menjadi kekuatan dalam merumuskan kebijakan pariwisata Kabupaten Siak.

\section{RUANG LINGKUP}

Ruang lingkup penelitian ini mencakup beberapa hal, yaitu:

1. Cakupan permasalahan tulisan ini terletak pada eksistensi kearifan lokal pada kebijakan pengembangan pariwisata menemui tantangan pada era globalisasi. Oleh sebab itu, evaluasi input kebijakan menjadi penting untuk dianalisis mengingat eksistensi budaya melayu akan dipengaruhi oleh dukungan input kebijakan

2. Batasan-batasan penelitian ini hanya berfokus pada sisi input dengan melacak sumber daya manusia, sarana dan prasarana dan rencana strategis pengembangan pariwisata serta dukungan anggaran yang ada untuk menyukseskan pelaksanaan kebijakan pariwisata di Kabupaten Siak.

3. Rencana hasil yang didapatkan akan diarahkan untuk menemukan bagaimana kondisi real sumber daya manusia yang ada pada pengembangan pariwisata di Kabupaten Siak sehingga menjadi dukungan atau justru menjadi penghambat pelaksanaan kebijakan. Selain itu tulisan ini juga akan menghasilkan elaborasi temuan dari sisi rencana strategis pemerintah dan anggaran yang dialokasikan untuk pelaksanaan kebijakan pengembangan pariwisata berbasis kearifan lokal.

\section{BAHAN DAN METODE}

Pada bagian ini akan disajikan kerangka teori sebagai bahan kajian dan metode penelitian yang digunakan sebagai berikut:

\subsection{Evaluasi Kebijakan CIPP}

Seringkali kebijakan publik dikaji hanya karena kebijakan tersebut dinilai bermasalah di permukaan atau terbukti mempunyai masalah pada prosesnya perumusannya, atau implementasinya bahkan evaluasinya. Penelitian kebijakan publik memiliki kecenderungan untuk mengonfirmasi runtutan proses teknis dan prosedural dengan fakta di lapangan sebagai justifikasi bahwa kebijakan publik tersebut bermasalah. Padahal, kebijakan publik adalah sebuah kajian yang punya dimensi luas, dapat dilihat dari kacamata politis, antropologi, sosiologis dan ekonomis. Sehingga perlu melihatnya dari banyak sisi ketimbang sisi administrasi dan yuridisnya saja.

Pembahasan mengenai permasalahan publik pun tidak ada habisnya karena setiap individu memiliki kepentingan yang berbeda-beda. Kepentingan yang berbeda-beda tersebut membuat pihak-pihak yang berkepentingan (stakeholders) bersuara dan ikut "menitipkan" suaranya. Proses tawar-menawar (bargaining) antar aktor pembuat kebijakan dengan menggunakan kebebasan dan kewenangannya bukan hal yang tabuh untuk dilakukan, dan bahkan kebebasan dan kewenangan tersebut sering disalahgunakan bukan untuk menyinkronkan kepentingan rakyat, melainkan untuk kekuasaan (power) (Anggara, 2014) .

Harus diakui bahwa kebijakan publik adalah tata kelola publik, bukan sekadar tata kelola negara. Sehingga tata kelola atau governance merupakan proses yang akan berkenaan dengan sistem politik yang dianut oleh sebuah negara dan bagaimana negara bertindak dalam aturan main yang telah dibuat. Indonesia adalah salah satu negara yang mengalami proses demokratisasi dalam sistem politiknya. Pada saat yang sama berlangsung pula perubahan besar terhadap tata kelola pemerintahannya. Sehingga keduanya hadir dalam momentum yang relatif hampir bersamaan.

Dalam proses evaluasi kebijakan publik tentu tidak dapat dilepaskan dari standar penilaian tertentu yang menjadi pedoman dalam mengevaluasi kebijakan Pengembangan beberapa indikator dalam evaluasi kebijakan dimaksudkan untuk menghindari timbulnya bias serta sebagai pedoman ataupun arahan bagi evaluator. Kriteria-kriteria yang ditetapkan menjadi tolak ukur dalam menentukan berhasil atau tidaknya suatu kebijakan publik. Bahwasanya evaluasi memberi informasi yang valid dan dapat dipercaya mengenai kinerja kebijakan, yaitu seberapa jauh kebutuhan, nilai, dan kesempatan telah dapat dicapai melalui tindakan publik. Dapat dikatakan bahwa evaluasi merupakan tahap akhir dari proses kebijakan sebelum kebijakan dihentikan atau dikaji ulang (Abidin, 2012). 
Salah satu model evaluasi kebijakan adalah model CIPP yang dikemukakan oleh Stufflebeam. Stufflebeam menjelaskan bahwa evaluasi kebijakan merupakan " $a$ study design and conducted to assist some audience and to asses an object's merit and worth" Salah satu model evaluasi kebijakan adalah model CIPP yang dikemukakan oleh Stufflebeam. Stufflebeam menjelaskan bahwa evaluasi kebijakan merupakan " $a$ study design and conducted to assist some audience and to asses an object's merit and worth". Dalam kajiannya mengenai evaluasi, Stufflebeam mengajukan pandangan mengenai model CIPP yang merupakan singkatan dari context evaluation, input evaluation, process evaluation, and product evaluation. Model CIPP ini merupakan pendekatan evaluasi yang berorientasi pada pengambilan keputusan.

“..... CIPP stands for evaluations of an entity's context, input, process, and product. Context evaluation assess needs, problems, assets and opportunities to help decisions makers define goals and priorities and help broader group of user judge goals, priorities and outcomes. Input evaluations assess alternative approaches, competing action plants and budgets for their feasibility and potential costeffectiveness to meet targeted needs and achieved goals.."

Awalnya model CIPP digunakan untuk mengevaluasi program pendidikan. Namun hingga kini, model CIPP telah digunakan untuk menganalisis berbagai bidang kajian. Ruang lingkup model CIPP terdiri atas 4 komponen, yaitu context, input, process, and product.

Dalam tulisan ini, penulis akan fokus pada evaluasi input sebab menjadi faktor penentu keberhasilan pelaksanaan sebuah kebijakan. Evaluasi input bertujuan untuk memberikan informasi dalam memanfaatkan sumber daya yang dimiliki. Melalui evaluasi input, maka akan diperoleh gambaran mengenai sumber daya dan strategi yang digunakan untuk mencapai tujuan. Informasi tersebut akan bermanfaat dalam menunjang terwujudnya efektifitas sebuah program kebijakan. Evaluasi input memberikan gambaran dalam menentukan sumber daya yang ada, alternatif yang dapat diambil, rencana serta strategi yang harus digunakan.

Komponen evaluasi masukan ini terdiri atas: a) sumber daya manusia, b) sarana dan prasarana serta sumber daya pendukung lainnya, c) dana atau anggaran, d) prosedur dan aturan yang diperlukan

\subsection{Metode Penelitian}

Penelitian ini merupakan penelitian kualitatif yang lebih mengutamakan penggunaan logika induktif dimana kategorisasi dilahirkan dari perjumpaan peneliti dengan informan di lapangan atau data-data yang ditemukan. Metode kualitatif adalah cara mengkaji kualitas-kualitas kehidupan keseharian yang mencakup rentang luas, yaitu from life's action and narratives to its sign, circumstances and sense of reality. Melalui pendekatan studi kasus, penelitian ini berusaha menggambarkan, menjelaskan dan menganalisis fenomena, peristiwa, aktivitas, kepercayaan, persepsi dan pemikiran secara individual dan kelompok.

Dalam penelitian ini dikumpulkan berbagai data yang diperoleh melalui pengamatan yang saksama, mencakup deskripsi dalam konteks yang detail disertai hasil wawancara yang mendalam dan hasil analisis dokumen. Data penelitian ini terdiri dari data primer dan data sekunder. Data primer adalah data yang diperoleh langsung dari informan penelitian dengan proses wawancara yang dijadikan objek penelitian. Teknik pemilihan informan dalam penelitian ini yaitu menggunakan teknik purposive. Penelitian ini dilakukan melalui teknik observasi, wawancara mendalam, dokumentasi.

Hal terakhir yang dilakukan adalah analisis data terhadap temuan substantif maupun temuan formal. Analisis data menjadi sebuah kegiatan yang dilakukan untuk mengatur, mengurutkan, mengelompokkan, memberi kode/tanda, dan mengategorikan data sehingga diperoleh temuan yang sesuai dengan masalah yang ingin dijawab. Analisis data dalam penelitian kualitatif adalah proses mencari dan menyusun secara sistematis data yang diperoleh dari hasil wawancara, catatan lapangan dan dokumentasi, dengan cara mengorganisasikan data ke dalam kategori, menjabarkannya ke dalam unit-unit, melakukan sintesa, menyusun ke dalam pola, memilih mana yang penting untuk dipelajari dan membuat kesimpulan. Dengan begitu, data akan mudah dipahami oleh peneliti sendiri maupun orang lain.

\section{PEMBAHASAN}

Perkembangan zaman dan masuknya arus globalisasi telah membawa pertumbuhan dan perkembangan pada berbagai sektor. Salah satu pengaruh yang nyata dirasakan ialah daerah yang terkenal dengan budaya tradisional melayu yaitu Kabupaten Siak. Pada awalnya, budaya melayu menjadi dasar dalam melaksanakan aktivitas masyarakat baik ekonomi, sosial, budaya, dan pembangunan. Masyarakat setempat masih memegang adat istiadat seperti tidak membangun rumah yang lebih tinggi dibandingkan istana dan mempertahankan atap "Salaso Jatuh Kembar". Namun seiring waktu, aspek modernitas semakin menggiurkan hingga mengaburkan unsur budaya melayu (Putra \& Astuti, 2017).

Meskipun demikian, promosi mengenai budaya melayu yang lekat dengan Kabupaten Siak tidak dapat begitu saja dihilangkan. Justru dalam pengembangan pariwisata, Kabupaten Siak secara tegas mengangkat budaya melayu sebagai daya tarik wisata. Terbukti dari Visi Kabupaten Siak yaitu "Terwujudnya Kabupaten Siak yang Maju dan Sejahtera dalam Lingkungan Masyarakat yang Agamis dan Berbudaya Melayu serta Menjadikan Kabupaten Siak sebagai Tujuan Pariwisata di Sumatera". 
Kebijakan pengembangan pariwisata di Kabupaten Siak mengacu pada UU No 10 tahun 2009 tentang Kepariwisataan dan UU No 11 Tahun 2010 tentang Cagar Budaya. Sesuai dengan UU Nomor 10 Tahun 2009 tentang Kepariwisataan yang bertujuan untuk menumbuhkan ekonomi masyarakat, maka Pemerintah Kabupaten Siak mendorong kemajuan destinasi wisata untuk dikunjungi berbagai wisatawan. Dinas Pariwisata Kabupaten Siak merupakan salah satu SKPD yang menyusun dan menetapkan rencana strategis (Renstra) di bidang pariwisata. Renstra berisi dokumen yang memuat visi ,misi, tujuan, sasaran kebijakan, program prioritas, termasuk juga permasalahan yang sedang dihadapi dunia pariwisata dan penyelesaiannya.

Pengembangan sektor pariwisata Kabupaten Siak dilaksanakan melalui program-program yang disesuaikan dengan tantangan dan harapan di era pasar bebas. Pengembangan pariwisata di Kabupaten Siak tidak dapat dilepaskan dari sumber daya manusia di Dinas Pariwisata Siak sebagai pelaksana utama kebijakan pariwisata Kabupaten Siak.

\subsection{SDM Dinas Pariwisata Kabupaten Siak}

Dalam menjalankan tugas dan fungsi pengembangan Pariwisata, Dinas Pariwisata Kabupaten siak mengakui bahwa keterbatasan utama mereka adalah kurangnya sumber daya manusia yang ahli di bidang kepariwisataan dan latar belakang pendidikan formal di bidang pariwisata. Sumber daya manusia memiliki peranan penting dalam mendukung pencapaian keberhasilan sebuah pembangunan bangsa. Secara sederhana dapat dikatakan bahwa, semakin tinggi kualitas sumber daya manusia maka akan semakin besar peluang untuk memperoleh keberhasilan di berbagai sektor.

Sumber daya manusia yang berdaya saing tinggi merupakan salah satu kunci keberhasilan di era globalisasi. Salah satu indikator daya saing sumber daya manusia dilihat dari pendidikannya. Berdasarkan data dari Renstra Dinas Pariwisata Kabupaten Siak 20172021, jumlah pegawai Dinas Pariwisata Kabupaten Siak adalah 139 orang, terdiri dari 54 orang PNS dan 85 orang pegawai honorer, seperti pada gambar 1 .

Gambar 1. Komposisi PNS dan Honorer Dinas Pariwisata Kabupaten Siak

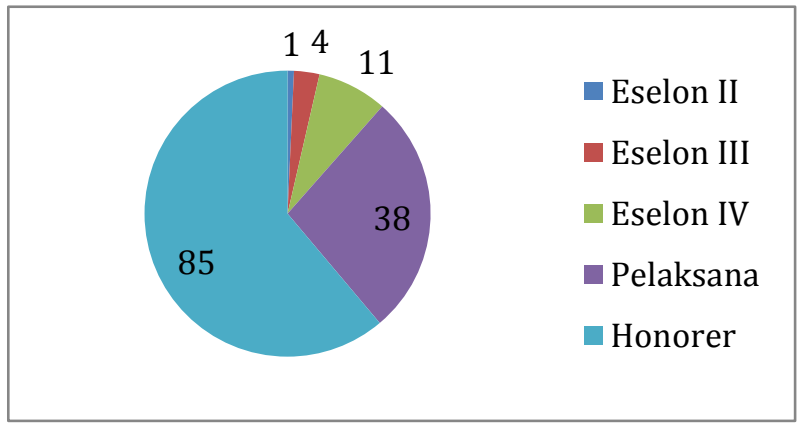

Permasalahan mendasar yang dihadapi adalah masih terbatasnya kuantitas dan kualitas sumber daya manusia pengelola. Dari data diatas, penjabaran tingkat pendidikan untuk pegawai yang berstatus PNSdan honorer dapat dilihat pada tabel 1 yang bersumber dari Renstra Dinas Pariwisata Kabupaten Siak tahun 20172021. Dari 54 orang PNS Dinas Pariwisata Kabupaten Siak, dapat diketahui bahwa pegawai yang berpendidikan SMA/SMK sederajat paling tinggi komposisinya. Pegawai yang berpendidikan sarjana baik D3 maupun S1 ternyata bukan berasal dari jurusan di bidang kepariwisataan.

Harus diakui bahwa daya saing sumber daya manusia bidang pariwisata di Indonesia masih rendah dibandingkan dengan Negara lain. Rendahnya daya saing tersebut dapat dilihat dari ketimpangan antara proporsi sumber daya manusia di level operasional dengan sumber daya manusia pada level manajemen, pemikir dan perencana. Salah satu penyebabnya adalah pendidikan dan keterampilan di SMK maupun universitas lebih memprioritaskan pada pelatihan praktis dibandingkan dengan pembekalan keilmuan guna menciptakan sumber daya manusia yang berkompetensi tinggi.

Hal ini tentu saja menjadi kendala yang sangat berarti dalam mengembangkan pariwisata di dinas Pariwisata sebagai pelaksana kebijakan pariwisata. Sedangkan 85 orang tenaga honorer, hanya beberapa pegawai yang menduduki tugas sebagai administrasi kantor yang berpendidikan D3. Sisanya berpendidikan mulai dari SD, SMP dan SMA. Ini menunjukkan bahwa dalam hal pendidikan tenaga honorer di Dinas Pariwisata juga memiliki pendidikan yang minim, seperti terlihat pada tabel 1.

\begin{tabular}{|c|c|c|}
\hline No & Pendidikan & Jumlah \\
\hline 1 & Strata Dua & 8 Orang \\
\hline 2 & Strata Satu & 19 Orang \\
\hline 3 & Diploma (D3) & 2 Orang \\
\hline 4 & SMA/SMK & 20 Orang \\
\hline 5 & SMP & - \\
\hline 6 & SD & 5 Orang \\
\hline & JUMLAH & 54 Orang \\
\hline
\end{tabular}

Tabel 1. Tingkat Pendidikan PNS di Dinas Pariwisata Kabupaten Siak

Beberapa catatan dalam pengembangan sumber daya pariwisata yang masih menjadi pekerjaan rumah di Dinas Pariwisata adalah

1. Kualitas dan kuantitas SDM bidang pariwisata masih belum mencukupi

2. Kebutuhan SDM dalam rangka pembangunan pariwisata pada jangka pendek, menengah dan jangka panjang masih belum teridentifikasi dengan baik 
3. Pengembangan dan peningkatan daya saing SDM dalam menghadapi tantangan nasional, regional maupun internasional belum maksimal

4. Kebijakan pemerintah dalam pengembangan SDM pariwisata belum sinkron

\subsection{Sarana dan Prasarana}

Selain faktor sumber daya manusia, keberhasilan pembangunan kepariwisataan juga ditentukan oleh sarana prasarana, ketersediaan fasilitas teknologi informasi yang sesuai dengan tuntutan zaman, serta dukungan finansial, kemitraan dan kelembagaan. Pada praktiknya, pengembangan pariwisata di Kabupaten Siak menghadapi beberapa kendala dalam hal sarana dan prasarana, diantaranya yaitu terbatasnya sarana dan prasarana di daerah tujuan wisata, seperti galeri, taman, budaya dan gedung kesenian yang belum fungsional.

Pengembangan pariwisata di Kabupaten Siak juga dihadapkan pada situasi belum optimalnya kesiapan pemerintah untuk bersaing di pasar global. Hal itu dibuktikan dengan minimnya pemanfaatan kemajuan teknologi komunikasi dan informasi sebagai salah satu sarana pemasaran dan promosi pariwisata. Sehingga berpengaruh pada kualitas dan kuantitas jumlah investasi di bidang pariwisata yang masih rendah. Berikut disajikan tabel kebutuhan sarana dan prasarana berdasarkan Laporan Akuntabilitas Kinerja Instansi Pemerintah (LAKIP) Dinas Pariwisata Kabupaten Siak tahun 2018.

Tabel 2. Kebutuhan Sarana dan Prasarana umum Pengembangan Pariwisata Kabupaten Siak

\begin{tabular}{|c|c|}
\hline $\begin{array}{l}\text { Sarana \& } \\
\text { Prasarana } \\
\text { Pariwisata } \\
\end{array}$ & Kebutuhan \\
\hline Aksesibilitas & $\begin{array}{l}\text { - Sarana alat transportasi baik darat maupun } \\
\text { sungai } \\
\text { - Prasarana penghubung seperti bandara dan } \\
\text { dermaga } \\
\text { - Kemudahan transportasi dalam informasi } \\
\text { rute, jadwal, dan reservasi moda }\end{array}$ \\
\hline $\begin{array}{l}\text { Prasarana } \\
\text { Umum }\end{array}$ & $\begin{array}{l}\text { - Listrik } \\
\text { - Air bersih } \\
\text { - Telkom } \\
\text { - Pengelolaan Limbah }\end{array}$ \\
\hline $\begin{array}{l}\text { Fasilitas } \\
\text { Umum }\end{array}$ & $\begin{array}{l}\text { - Keamanan } \\
\text { - Perbankan/atm/money changer } \\
\text { - Parkir } \\
\text { - Rumah Ibadah } \\
\text { - Sanitasi }\end{array}$ \\
\hline $\begin{array}{l}\text { Fasilitas } \\
\text { Pariwisata }\end{array}$ & $\begin{array}{l}\text { - Akomodasi } \\
\text { - Rumah makan } \\
\text { - Informasi layanan wisata } \\
\text { - Keimigrasian } \\
\text { - Pusat souvenir } \\
\text { - Papan informasi dan penunjuk arah } \\
\text { - Panggung pagelaran } \\
\text { - Pedestrian }\end{array}$ \\
\hline
\end{tabular}

Memang tidak dapat dipungkiri, bahwa tantangan yang harus dihadapi dalam pengembangan pariwisata masih ada. Berdasarkan data dari Dinas Pariwisata Kabupaten Siak, beberapa tantangan tersebut diantaranya yaitu:

1. Meningkatnya daya saing kepariwisataan dari daerah lain

2. Investasi yang ada belum berorientasi pada pemberdayaan sumber daya lokal

3. Pengaruh negative dari kebudayaan asing yang berkembang di masyarakat

4. Infrastruktur dan fasilitas wisata dan ekonomi kreatif belum mendukung

5. Rendahnya dukungan dari organisasi profesi, pelaku kebudayaan dan dunia usaha

6. Terjadinya kesenjangan pembangunan antar kawasan wisata

7. Sinergisitas antara eksekutif dan legislative dalam melaksanakan kebijakan pembangunan wisata masih belum optimal dilakukan

\subsection{Rencana Strategis Pengembangan Pariwisata Kabupaten Siak}

Keragaman tradisi daerah wisata telah menjadikan Kabupaten Siak sebagai salah satu destinasi wisata yang kaya dengan berbagai bentuk dan dimensi tujuan wisata, seperti seni rupa, seni budaya, pertunjukan dan upacara tradisional. Pengembangan seni, budaya dan tradisi memiliki peranan penting dalam meningkatkan apresiasi masyarakat terhadap keragaman budaya dan memiliki sikap adaptif terhadap pengaruh budaya global yang positif bagi kemajuan sebuah daerah. Jika dilihat berdasarkan hasil pengukuran kinerja sasaran Dinas Pariwisata Kabupaten Siak tahun 2018, keseluruhan indikator dan target kinerja sasaran strategis dinilai "sangat baik". Penilaian itu didasarkan pada empat sasaran strategis yang ditetapkan.

1. Meningkatnya promosi pariwisata Kabupaten Siak

Hal pertama yang dilakukan oleh Dinas Pariwisata selaku pelaku utama pengembangan pariwisata Kabupaten Siak adalah melakukan promosi pariwisata. Bukan saja bertujuan untuk mengenalkan destinasi pariwisata, tetapi juga sebagai langkah menumbuhkan kesadaran wisatawan terkait nilai-nilai yang terkandung dalam sebuah objek wisata

Kabupaten Siak sudah memiliki modal di bidang regulasi dan program dalam melakukan pengembangan kebudayaan. Salah satunya adalah melalui visi daerah yang berorientasi pada kebudayaan dan pariwisata, tersedianya roadmap kebudayaan melayu dan PERDA yang mengatur tentang bahasa dan pakaian melayu.

Untuk melihat pencapaian sasaran promosi pariwisata di Kabupaten Siak, dapat dilihat pada tabel 3. 
Tabel 3. Pencapaian Sasaran Promosi Pariwisata

\begin{tabular}{|c|c|c|c|}
\hline $\begin{array}{l}\text { Sasaran } \\
\text { Strategis }\end{array}$ & $\begin{array}{l}\text { Indikator } \\
\text { Kinerja } \\
\text { Sasaran } \\
\end{array}$ & Target & Realisasi \\
\hline \multirow{7}{*}{$\begin{array}{l}\text { Meningkat } \\
\text { nya } \\
\text { Promosi } \\
\text { Pariwisata }\end{array}$} & $\begin{array}{l}\text { Jumlah } \\
\text { Wisatawan }\end{array}$ & $\begin{array}{l}220.000 \\
\text { orang }\end{array}$ & $\begin{array}{l}387.038 \\
\text { orang }\end{array}$ \\
\hline & $\begin{array}{l}\text { Lama Tinggal } \\
\text { Wisatawan }\end{array}$ & 1 Hari & 1 Hari \\
\hline & $\begin{array}{l}\text { Jumlah PAD } \\
\text { Retribusi } \\
\text { sektor } \\
\text { Pariwisata } \\
\end{array}$ & $\begin{array}{l}\mathrm{Rp} \\
1.000 .000 .0 \\
00\end{array}$ & $\begin{array}{l}\mathrm{Rp} \\
1.486 .262 .00 \\
0\end{array}$ \\
\hline & Jumlah Event & 13 event & 11 event \\
\hline & $\begin{array}{l}\text { Jumlah } \\
\text { Promosi pada } \\
\text { media cetak }\end{array}$ & 4 kali & 4 kali \\
\hline & $\begin{array}{l}\text { Jumlah } \\
\text { promosi pada } \\
\text { media } \\
\text { elektronik } \\
\end{array}$ & 3 kali & 3 kali \\
\hline & $\begin{array}{l}\text { Jumlah kerja } \\
\text { sama } \\
\text { pariwisata } \\
\text { yang terjalin }\end{array}$ & $\begin{array}{l}5 \text { dokumen } \\
\text { perjanjian }\end{array}$ & $\begin{array}{l}11 \text { dokumen } \\
\text { perjanjian }\end{array}$ \\
\hline
\end{tabular}

Berdasarkan tabel Laporan Akuntabilitas Kinerja Instansi Pemerintah (LAKIP) Dinas Pariwisata Kabupaten Siak tahun 2018, rata-rata pencapaian kinerja sebesar $100 \%$. Pencapaian tersebut diperoleh dengan dukungan dari kegiatan pengembangan jaringan kerja sama promosi pariwisata, pelaksanaan promosi pariwisata nusantara di dalam dan luar negeri, serta melakukan pengadaan bahan promosi.

Meskipun tabel diatas menunjukkan pencapaian promosi pariwisata sebesar $100 \%$, namun promosi pariwisata ini masih memiliki banyak keterbatasan. Selama satu tahun, target promosi baik media cetak maupun elektronik terbilang sangat sedikit hanya 3 hingga 4 kali. Padahal promosi pariwisata di era modern seperti saat ini telah bergeser melalui promosi digital atau e-tourism. Promosi secara digital dapat memanfaatkan website, media sosial, dan aplikasi lainnya. Proses promosi ini terbilang efektif untuk menyasar wisatawan di era industry 4.0 yang mengandalkan informasi wisata dari media sosial. Selain itu, promosi seperti ini terbilang murah dibandingkan dengan promosi konvensional.

Namun promosi yang memanfaatkan teknologi informasi dan komunikasi ini masih belum dapat maksimal dilakukan oleh Dinas Pariwisata Kabupaten Siak. Hal itu diakui pula oleh Bapak Aris Darma, S.I.Kom selaku Kasubag. Humas di Kantor Bupati Kabupaten Siak bahwa:

"Promosi pariwisata Kabupaten Siak masih belum maksimal dilakukan. Hal itu dikarenakan promosi kurang memanfaatkan teknologi informasi secara komprehensif sebagai sarana pemasaran dan promosi pariwisata." (Wawancara pada tanggal 12 Juni 2020)

2. Meningkatnya Daya Saing Destinasi dan Industri
Pariwisata
Pariwisata menjadi salah satu yang mampu meningkatkan penerimaan daerah. Sehingga wajar jika daerah yang memiliki potensi wisata berusaha untuk meningkatkan daya saing destinasi dan industri pariwisata. Upaya yang dapat dilakukan untuk menumbuh kembangkan industry pariwisata adalah dengan menyiapkan sarana akomodasi yang memadai, promosi pariwisata, kemudahan perjalanan, mengupayakan produk baru di objek wisata (Walu \& Bagus, 2018).

Berkembangnya sektor ini dapat membawa dampak yang cukup besar terhadap industri lain di sekitarnya, seperti hotel, rumah makan, biro travel, hingga UMKM. Perilaku masyarakat yang ramah turis dan objek wisata yang dikemas secara menarik merupakan wujud kecerdasan pariwisata. Dilihat dari daya saing destinasi dan industri pariwisata Kabupaten Siak dengan membandingkan capaian realisasi dari target yang telah ditetapkan seperti pada tabel 4.

Tabel 4. Daya Saing Destinasi dan Industri Pariwisata

\begin{tabular}{|c|c|c|c|}
\hline $\begin{array}{l}\text { Sasaran } \\
\text { Strategis }\end{array}$ & $\begin{array}{l}\text { Indikator } \\
\text { Kinerja } \\
\text { Sasaran }\end{array}$ & Target & Realisasi \\
\hline \multirow{2}{*}{$\begin{array}{l}\text { Meningkatnya } \\
\text { daya saing } \\
\text { destinasi dan } \\
\text { industri } \\
\text { pariwisata }\end{array}$} & $\begin{array}{l}\text { Jumlah } \\
\text { destinasi } \\
\text { pariwisata } \\
\text { yang baik } \\
\text { dan berdaya } \\
\text { saing }\end{array}$ & 5 destinasi & 5 destinasi \\
\hline & $\begin{array}{l}\text { Jumlah } \\
\text { industri } \\
\text { pariwisata } \\
\text { yang baik } \\
\text { dan berdaya } \\
\text { saing }\end{array}$ & $\begin{array}{l}10 \text { industri } \\
\text { pariwisata }\end{array}$ & $\begin{array}{l}10 \text { industri } \\
\text { pariwisata }\end{array}$ \\
\hline
\end{tabular}

Berdasarkan tabel 4, Laporan Akuntabilitas Kinerja Instansi Pemerintah (LAKIP) Dinas Pariwisata Kabupaten Siak tahun 2018, dapat diketahui bahwa sasaran Dinas Pariwisata dalam meningkatkan daya saing pariwisata dan industri pariwisata menunjukkan capaian sebesar $100 \%$. Capaian daya saing pariwisata yang ditampilkan oleh Dinas Pariwisata menunjukkan capaian sangat baik yaitu $100 \%$. Namun jika ditelaah kembali, dari sekian banyak objek wisata yang ada di Kabupaten Siak, ternyata hanya 5 objek wisata yang berdaya saing tinggi. Realita ini justru menunjukkan bahwa sesungguhnya daya tawar objek wisata kabupaten Siak masih banyak yang belum sesuai dengan standar. 


\section{Produktivitas dan Akses Ekonomi Kreatif}

Pengembangan pariwisata selalu berkorelasi dengan pengembangan ekonomi kreatif masyarakat. Sebagai daerah yang menjadi tujuan wisata, hadirnya karya seni rupa dan ekonomi kreatif di lokasi objek wisata menjadi sebuah bentuk penguatan sektor pengembangan pariwisata. Keberhasilan pengembangan pariwisata ditentukan oleh dukungan banyak pihak termasuk pelaku seni rupa dan ekonomi kreatif.

Pengembangan ekonomi kreatif yang dilakukan oleh Kabupaten Siak bekerja sama dengan Badan Ekonomi Kreatif (Bekraft) pusat dan Bandung Creative City Forum (BCCF). Kerja sama ini penting mengingat BCCF merupakan salah satu komunitas yang diakui UNESCO dalam mengembangkan ekonomi kreatif. Sedangkan Bekraft juga tertarik untuk mengembangkan ekonomi kreatif di Siak selain di Bandung dan Bojonegoro. Ada sekitar 16 sektor di Siak yang dikembangkan oleh pengrajin Siak. Pada tahun 2018, jumlah produktivitas dan pemanfaatan sarana prasarana yang digunakan sebagai akses ekonomi kreatif dapat dilihat pada tabel 5 .

Tabel 5. Produktivitas dan Akses Ekonomi Kreatif

\begin{tabular}{|c|c|c|c|}
\hline $\begin{array}{l}\text { Sasaran } \\
\text { Strategis }\end{array}$ & $\begin{array}{l}\text { Indikator } \\
\text { Kinerja } \\
\text { Sasaran }\end{array}$ & Target & Realisasi \\
\hline \multirow{2}{*}{$\begin{array}{l}\text { Meningkatnya } \\
\text { produktivitas } \\
\text { dan akses } \\
\text { ekonomi kreatif }\end{array}$} & $\begin{array}{l}\text { Jumlah sarana } \\
\text { dan prasarana } \\
\text { yang dibangun }\end{array}$ & $\begin{array}{l}5 \text { sarana } \\
\text { dan } \\
\text { prasarana }\end{array}$ & $\begin{array}{l}5 \text { sarana } \\
\text { dan } \\
\text { prasarana }\end{array}$ \\
\hline & $\begin{array}{l}\% \text { sarana dan } \\
\text { prasarana yang } \\
\text { dimanfaatkan }\end{array}$ & $95 \%$ & $95 \%$ \\
\hline
\end{tabular}

Tabel diatas menunjukkan data mengenai peningkatan produktivitas dan akses ekonomi kreatif yang dilihat dari sarana dan prasarana yang mampu dimanfaatkan. Pencapaian ini dikatakan sangat baik sebab dalam menjalankan program ekonomi kreatif masyarakat memanfaatkan sarana dan prasarana yang telah disediakan pemerintah. Sebagai salah satu kabupaten yang menjalin kolaborasi secara nasional melalui Bekraf, objek wisata yang ada di Kabupaten Siak memiliki kesempatan untuk memperoleh stimulus dalam mengembangkan produk UMKM agar dapat berdaya saing nasional hingga internasional.

\subsection{Dukungan Anggaran}

Pencapaian sasaran diatas tidak dapat dilepaskan dari dukungan finansial yang sudah dianggarkan dalam Anggaran Pendapatan dan Belanja Daerah (APBD) sebesar Rp 20.936.816.733,- pada tahun 2018. Jumlah ini terdiri dari Rp 5.151.502.033,- yang digunakan untuk belanja tidak langsung seperti gaji dan tunjangan pegawai dan untuk belanja langsung sebesar Rp 17.035.314.700,- yang digunakan untuk membiayai kegiatan yang dilaksanakan oleh Dinas Pariwisata Kabupaten Siak. Diketahui bahwa program dan kegiatan yang dilaksanakan oleh Dinas Pariwisata Kabupaten Siak terdiri dari 1 urusan, 3 program dan 38 kegiatan. Penyerapan anggaran pada Dinas Pariwisata masih belum maksimal disebabkan oleh keterbatasan sumber daya aparatur yang terlibat dalam pengelolaan kegiatan, keterbatasan sarana dan prasarana serta adanya kegiatan yang tidak dilaksanakan.

\section{KESIMPULAN}

Eksistensi kearifan lokal pada kebijakan pariwisata di Kabupaten Siak tidak terlepas dari dukungan input yang ada. Berkaca pada pesona pariwisata yang ditampilkan di Kabupaten Siak, maka budaya melayu menjadi daya tarik utama pada pengembangan pariwisata. Ditambah lagi pada aspek konteks masyarakat setempat yang mendukung pelaksanaan kebijakan pariwisata berbasis kearifan lokal. Ini menunjukkan bahwa kearifan lokal di bidang pariwisata Kabupaten Siak masih terbukti eksis di tengah tuntutan dan tantangan di era globalisasi. Aspek ini menjadi hal fundamental dari aspek input dan proses yang mempengaruhi keberhasilan pelaksanaan sebuah kebijakan. Dukungan input tersebut terdiri atas kualitas sumber daya manusia, sarana dan prasarana yang disediakan serta rencana strategis pengembangan pariwisata.

\section{SARAN}

Penelitian mengenai kebijakan publik berbasis kearifan lokal selalu menarik untuk ditelisik. Agar dapat mengoptimalkan pengembangan kebijakan pariwisata berbasis kearifan lokal Dinas Pariwisata perlu menjalin koordinasi secara intensif dengan Lembaga Adat Melayu Riau selaku pengontrol kebudayaan melayu di Kabupaten Siak. Oleh sebab itu, penelitian ke depan juga perlu melihat sinergisitas antar lembaga dalam mendukung keberhasilan kebijakan berbasis kearifan lokal sebagai bagian dari input kebijakan pengembangan pariwisata.

\section{DAFTAR PUSTAKA}

Abidin, S. Z. (2012). Kebijakan Publik. Jakarta: Salemba Humanika.

Adi, S. W., \& Saputro, E. P. (2017). Potensi Daya Tarik Wisata Sejarah Budaya. Seminar Nasional Riset Manajemen \& Bisnis:Perkembangan Konsep dan Riset e-Business di Indonesia, (pp. 744-749). Surakarta.

Alam, S. (2012). Analisis Kebiajakan Publik: Kebijakan Sosial Perkotaan sebagai Sebuah Kajian Implementatif. Jurnal Ilmiah Ilmu Pemerintahan, 82.

Anggara, S. (2014). Kebijakan Publik. Bandung: Pustaka Setia.

Artis. (2016). Branding "Siak The Truly Malay" oleh Dinas Pariwisata Kabupaten Siak. Komunikasiana Vol 1 Nomor 1, 10-20. 
Balquini, d. (2010). Pariwisata Berkelanjutan dalam Pusaran Krisisi Global. Bali: Udayana Press.

Bialostocka, O. (2014). Using the Past to Build the Future: A Critical Review of The Liberation Heritage Route Project of South Africa. Africa Insight 44(2), 94-107.

Bullen, P., \& Love, P. (2011). Adaptive reuse of Heritage Building. Structural Survey 29(5), 411-421.

Caraba, C. (2011). Communist Heritage Tourism and Red Tourism: Concept, Development and Problems. Cina Continents 1(1), 29-39.

George, E. (2010). Intangible Cultural Heritage, ownership, copyright, and tourism. International Journal of Culture, Tourism, and Hospitality Research 4(4), 376-388.

Hariyanto, L. O. (2015). Materi Paparan Sadar Wisata dan Sapta Pesona. Bandung: Dinas Pariwisata Provinsi Jawa Barat.

Irianto, A. M. (2016). Komodifikasi Budaya di Era Ekonomi Global Terhadap Kearifan Lokal. Theologia Vol 27 Nomor 1, 213-236.

Jupir, M. M. (2013). Implementasi Kebijakan Pariwisata Berbasis Kearifan Lokal (Studi di Kabupaten Manggarai Barat). Journal of Indonesian Tourism and Development Studies Vol 1 No 1, 28-36.

Karim, A. B. (2010). Pariwisata:Antara Tuntutan Industri dan Kearifan Lokal. Jurnal Karsa Vol XVIII No 2, 147-159.

Putra, F. A., \& Astuti, P. (2017). Kebijakan Pengembangan Area Permukiman Melayu Modern di Siak Sri Indrapura, Provinsi Riau. Seminar Nasional Perencanaan Pembangunan Inklusif Desa Kota (p. 33). Padang: Pasca Unand.

Rahmi, S. A. (2016). Pembangunan Pariwisata dalam Perspektif Kearifan Lokal. Reformasi Vol 6 No 1.

Rogerson, C., \& Merwe, V. D. (2016). Heritage Tourism in The Global South : Development impact of the Cradle of Humankind World Heritage Site, South Africa. Local Economy 31(1-2), 234-248.
Rosadi, S., \& Medayanti, M. D. (2019). Strategi City Branding oleh Pemerintah Daerah Kabupaten Siak dalam Peningkatan Daya Tarik Pariwisata. Jurnal Wedana Volume V No 2, 16-20.

Sahubawa, A., Antariksa, \& F.Usman. (2010). Kawasan Bersejarah Kota Tua Hindia Belanda di Bandaneira, Maluku. Arsitektur e-Journal 3(1), 1-13.

Salam, N. E., \& Nurjanah. (2019). Komunikasi Pariwisata Budaya dalam Mempromosikan City Branding "Siak the Truly Malay". Profesi Human Vol 4 No 1, 134-152.

Santoso, P. (2010). Modul Pembelajaran Analisis Kebijakan Publik. Yogyakarta: Polgov Jurusan Politik dan Pemerintahan UGM.

Shankar, S. (2015). Impact of Heritage Tourism in India : A case Study . International Journal of Innovative Research in Information Security (IJIRIS) 6(2), 5961.

Stufflebeam, D. (2003). The CIPP Model for Evaluation. In T. Kellaghan, \& D. S. (eds), International Handbook of Educational Evaluation (pp. 31-62). Dorrdrecht: Kluwer Academic Publisher.

Sumada, I. M. (2017). Peranan Kearifan Lokal dalam Perspektif Kebijakan Publik. Jurnal Ilmu Politik dan Komunikasi Vol VII No 1, 117-124.

Suneki, S. (2012). Dampak Globalisasi terhadap Eksistensi Budaya Daerah. Jurnal Ilmiah Civis Vol 21 No 1, 307-319.

Walu, K. J., \& Bagus, N. (2018). Analisis Peran Dinas Pariwisata dalam Pengembangan Pariwisata Kota Baru. Jurnal Ilmu Sosial dan Ilmu Politik Vol 8 Nomor 3 .

\section{UCAPAN TERIMA KASIH}

Penulis menguapkan terima kasih kepada LPPM

Universitas Riau selaku pemberi Hibah Penelitian dalam skema Penelitian Dosen Muda 